\title{
A KLÍMAVÁLTOZÁS ÉS A LÉGSZENNYEZÉS HELYZETE ÉS VÁLTOZÁSAI
}

\author{
Szűcs Csaba
}

\section{Összefoglalás}

A globális klimaváltozás súlyos fenyegetést jelent a Föld lakói számára. A földi éghajlatra tett emberi hatások csökkentése szülkségszerü, hogy minimalizáljuk a széllöséges idöjárási események káros követkęményeit. Ennek megfelelöen sürgös feladat a globális, a regionális és a nemzeti szintü intéz̨eedések kidolgozása. Az ENSZ Éghajlatváltozási Kormánykëozi Testülete (IPCC) megerösiti az̨t a tényt, hogy emberi tevékenység áll a globális átlaghömérséklet-emelkedés hátterében. A jelentés ismerteti, hogy a növekvő ÜHG kibocsátás változásokat okoz. az. óceánokban, hat a sarki jégsapkékra, illetve a bioszféra és az éghajlati rendszer más elemeire is. A globális klimaváltozást minden eszkëzzel mérsékelni kell. Munkám során vizsgálom légszennyezó anyag kibocsátást Magyarországon. Bemutatom a föbb indikátorok változásainak trendjét.

Kulcsszavak: klimaváltozás, fenntarthatóság, indikátorok, energiatermelés, széndioxid kibocsátás JEL: $Q^{42}$

\section{THE SITUATION AND EFFECTS OF CLIMATE CHANGE AND AIR POLLUTION}

\begin{abstract}
Global climate change poses a serious threat to the inhabitants of the Earth. Reducing buman impacts on the Earth's climate is necessary to minimize the adverse consequences of extreme weather events. Accordingly, there is an urgent need to develop action plans at global, regional and national levels. The United Nations Intergovernmental Panel on Climate Change (IPCC) confirms the fact that human activity is behind the rise in global average temperatures. The report explains that increasing GHG emissions cause changes in the oceans, affect polar ice caps as well as the biosphere and other elements of the climate system. Global climate change must be mitigated by all means. In the course of my work. I study airpollutant emissions in Hungary and present the trends of changes in the main indicators.
\end{abstract}

Keywords: climate change, sustainability, indicators, energy production, carbon dioxide emissions

JEL: $Q^{42}$ 


\section{Bevezetés}

A globális klímaváltozás a Föld, élő rendszerei számára súlyos fenyegetés. Csete - Láng (2005) az éghajlatváltozást korunk nagy gazdasági, társadalmi és környezeti problémájának tartja. A jelenlegi tények a klímaváltozásról a következők:

- Száz év alatt Európában 1oC-al nőtt az éves átlaghőmérséklet;

- A légkör széndioxid koncentrációja folyamatosan nő és mára magasabb, mint bármikor;

- A sarkok jegének vastagsága 40\%-kal csökkent;

- Az időjárási anomáliák gyakorisága és súlyossága növekszik;

- Az átlagos tengerszint 100 év alatt 15-20 cm-t emelkedett;

- Az ember okozta üvegházhatás kétharmadáért a CO2 felelős;

- A nyári hónapok jelentősen melegebbekké váltak.

Az MTA VAHAVA projektje szerint a hőmérséklet hazánkban növekedni fog és szélsőséges időjárási viszonyokra kell készülni.

A globális klímaváltozással és fenntarthatósággal számos szerző foglalkozott, említhetők Láng et al. (2007), Magda R. (2010), Marselek (2005), Marselek (2006) és Godrej (2004) munkái. Lorenz (1973) negatívan nyilatkozik a civilizált emberiség jövőt tönkretevő szerepéről.

Az Európai Unió a jövőre vonatkozó elképzeléseket tett közzé az Európa 2020 elemzésben (European Commission, 2010).

Jelenleg az Európai Zöld Megállapodás reménykeltő célokat kíván megvalósítani a klímaváltozás visszafogása érdekében.

\section{Anyag és módszer}

Munkám során statisztikai adatokat felhasználva bemutatom a klímaváltozás várható hatásait és utalok a fenntarthatóság megvalósításának lehetőségére.

Az indikátorok változásait trendek bemutatásával értékelem és következtetéseket vonok le. Széleskörű irodalmi áttekintésemben a téma jó ismerőinek véleményeire utalok.

\section{Eredmények}

Az időjárás változásai folyamatosan nyomon követhetők és ez alapján egyértelmû a melegedés ténye. Az eddigi klímacsúcsok nem hoztak áttörést főleg az USA és Kína magatartása miatt. A párizsi megállapodás inkább csak az egyetértésre utal, az eredmények csekélyek. Az Európai Zöld megállapodás ambiciózus terv, de kérdéses, hogy az átállás nem okoz-e túl nagy gazdasági visszaesést egyes országokban.

\section{Változások az idöjárásban}

A hazai fenntarthatósági célkitűzések között szerepel a klímaváltozás elleni küzdelem, ami az üvegházhatású gázok légkörbe való kibocsátásának csökkentésével segíthető elő. Az éves középhőmérséklet Budapesten folyamatosan növekszik (1. ábra). 


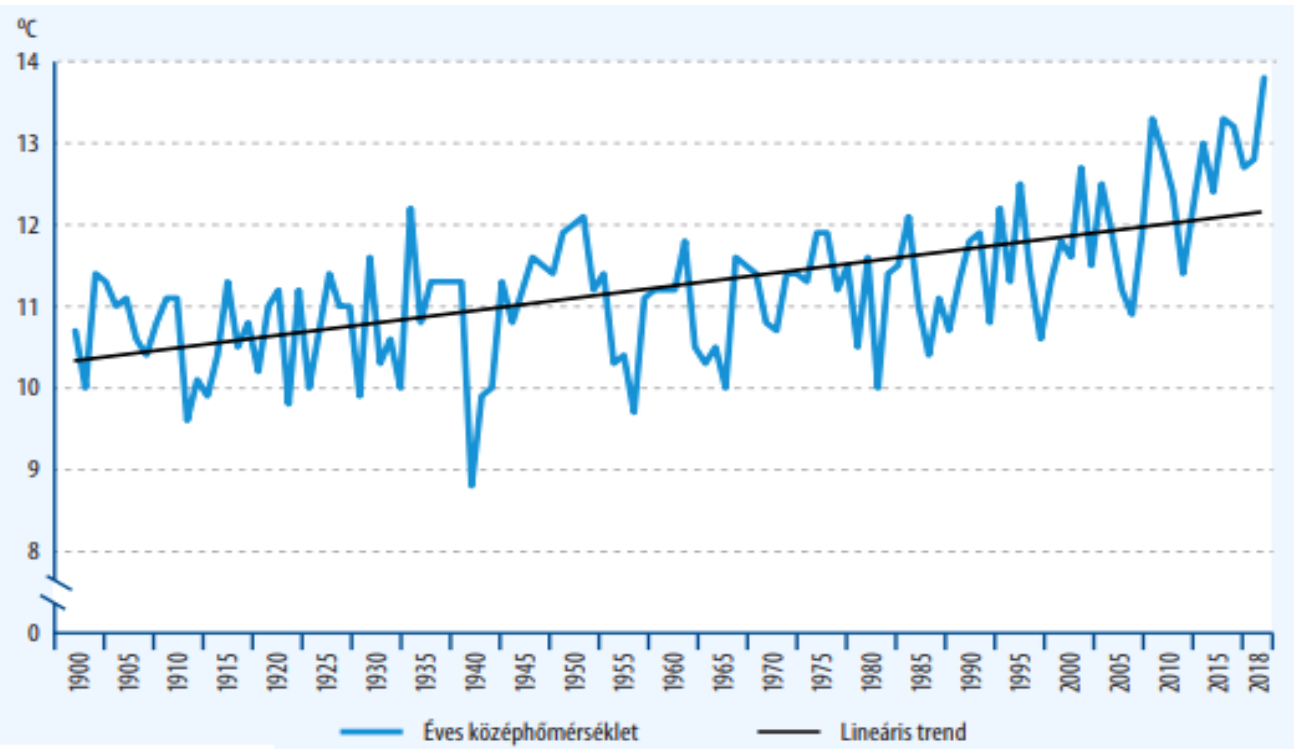

1. ábra: Az éves középhőmérséklet Budapesten

Forrás: Országos Meteorológiai Szolgálat, KSH, 2018.

A lehullott csapadék éves mennyisége kismértékben csökkent (2. ábra).

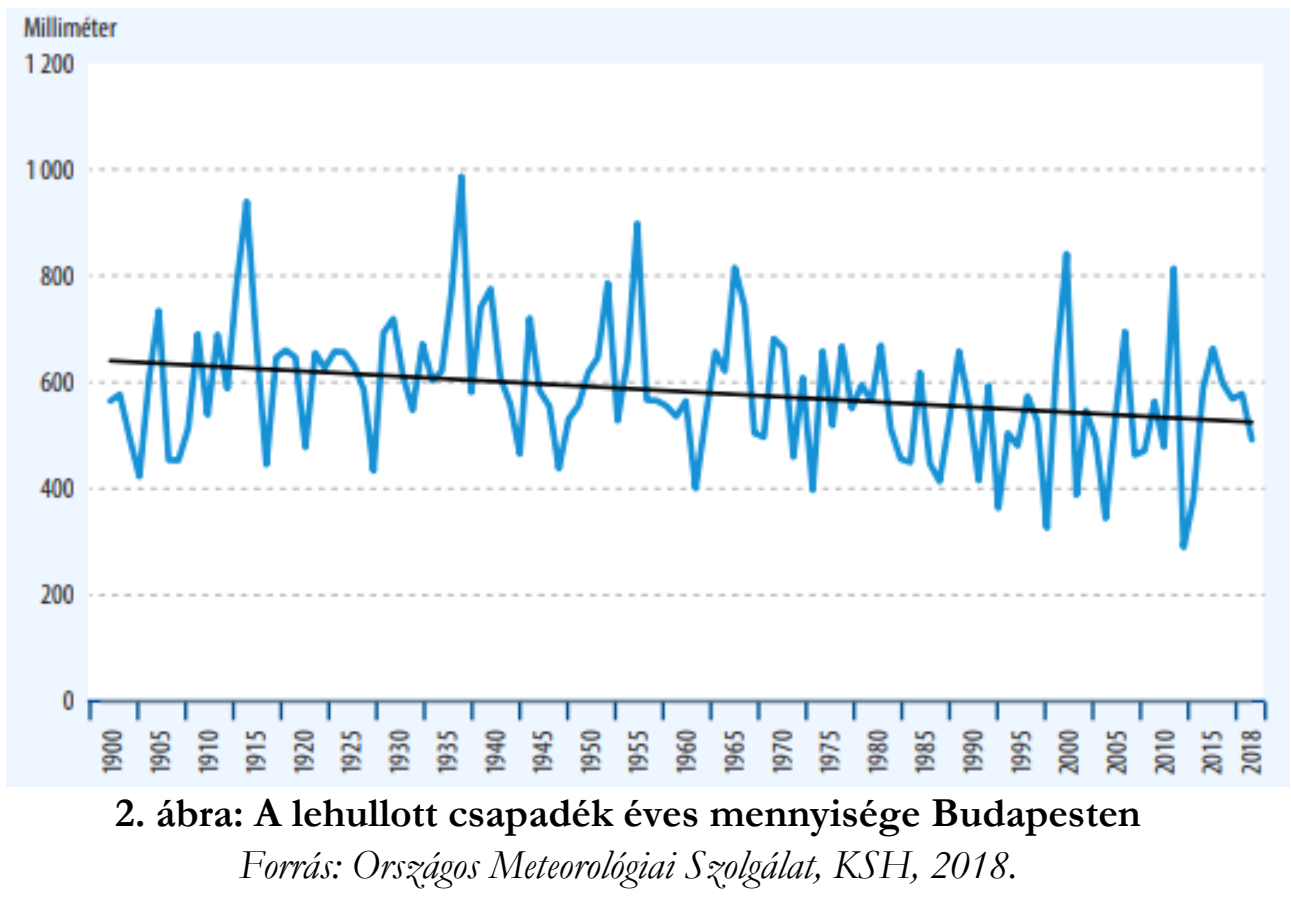

A hőségnapok száma növekszik, a fagyos napok száma csökken (3. ábra). 


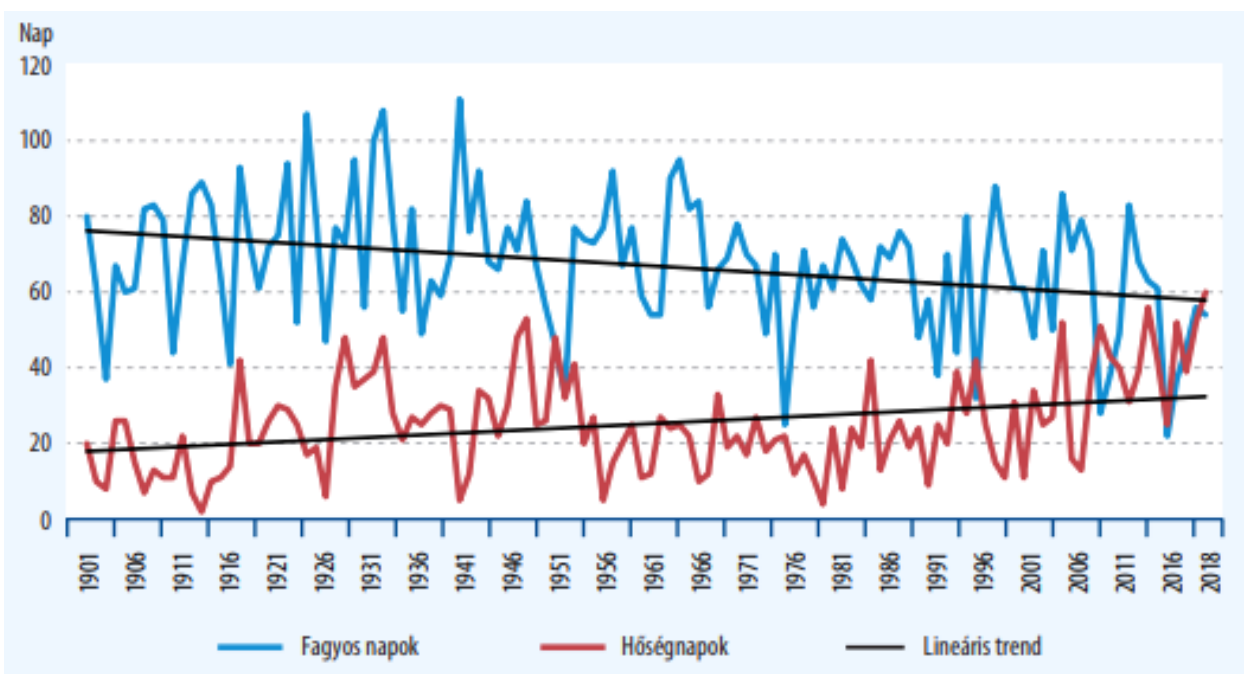

3. ábra: A hőség- és fagyos napok száma Budapesten

Forrás: Országos Meteorológiai Szolgálat, KSH, 2018.

A hőhullámmal érintett napok száma is emelkedik (4. ábra).

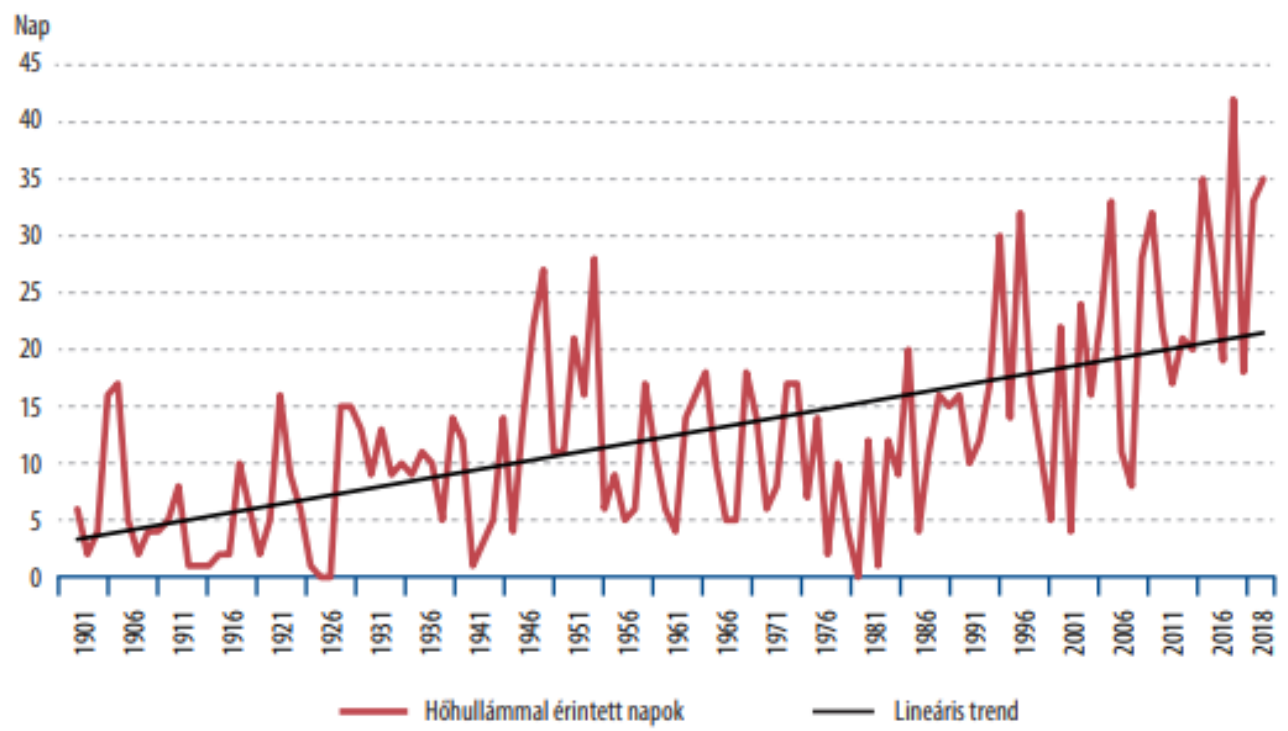

4. ábra: A hőhullámmal érintett napok száma Budapesten

Forrás: Országos Meteorológiai Szolgálat, KSH, 2018.

\section{Eddigi klímacsúcsok eredményei}

A fenntartható fejlődés megvalósítása esetén a klímaváltozás mérsékelhető. Láng (2003) kifejti az ehhez kapcsolódó alappilléreket. A Stockholmi Konferencián alakult ki a természeti-környezeti pillér, a Riói Konferencián a gazdasági pilléren volt a hangsúly, a Johannesburgi Konferencián pedig a társadalmi-szociális pillér került előtérbe.

Az 1997-ben aláírt Kiotói Egyezményben a résztvevő iparosodott államok elvállalták, hogy CO2 kibocsátásukat az aláírást követő évtizedben 5,2 százalékkal az 1990-es szint alá szorítják vissza. 2006 decemberéig 169 állam csatlakozott az egyezményhez. 
További konferenciák voltak (Koppenhága 2009, Canain 2010, Durban 2011), ahol nem volt megegyezés. 2012 végén Dohában megegyeztek az érintett államok, hogy a Kiotói jegyzőkönyv érvényét 2020-ig meghosszabbítják.

A 2015-ös Párizsi klímakonferencia eredményt hozott. 195 ország volt résztvevő és mindenkinek el kellett fogadni az egyezmény végső szövegét. A klímacsúcs célja egy globális megállapodás elfogadása volt, melynek betartásával sikerülhet visszaszorítani a klímaváltozást és $20 \mathrm{C}$ alatt tartani az átlaghőmérséklet növekedést. Az egyezményt a jelentős környezetszennyezést okozó országok is aláírták.

A megállapodásnak nincs szankcionáló ereje, önkéntes megállapodásokon alapul és a teljesítés elmulasztása nem büntethető. Ilyen feltételek mellett a CO2 kibocsátás csökkentése kétséges.

\section{Az Európai Zöld Megállapodás céljai}

Az Európai Unió 1990 és 2018 között 23 százalékkal csökkentette az üvegházhatású gázkibocsátását a gazdaság 61 százalékos növekedése mellett. A cél Európa klímasemlegességének elérése 2050-re, vagyis az üvegházhatású gázkibocsátás mértékének nettó nullára csökkentése.

Az Európai Zöld Megállapodás [COM (2019) 640 final] célja az éghajlat és környezetvédelmi kihívások kezelése.

Az Európai Bizottság nyolc szakpolitikai területen javasol új intézkedéseket. A célkitűzések a következők:

- Az EU 2030-ra és 2050-re vonatkozó éghajlatvédelmi törekvéseinek fokozása;

- Az ipar mozgósítása a környezetbarát és körforgásos gazdaság érdekében;

- A fenntartható és intelligens mobilitásra való átállás felgyorsítása;

- Tiszta, megfizethető és biztonságos energiaellátás;

- Az ökoszisztémák és a biológiai sokféleség megóvása és helyreállitása;

- Energia- és erőforrás hatékony építés és korszerűsítés;

- Szennyezőanyag-mentességi célkitűzés a toxikus anyagoktól mentes környezetért;

- A termelőtől a fogyasztóig méltányos, egészséges és környezetbarát élelmiszerrendszer kialakítása.

A célok csak széleskörű beruházások mellett valósíthatók meg. Az Európai Bizottság közleménye bemutatja a Fenntartható Európa beruházási tervet [COM (2020) 21 final].

A 2030-ra kitűzött célok:

- Az üvegházhatást okozó gázok kibocsátásának legalább 40 százalékos csökkentése az 1990es szinthez képest.

- A megújuló energia részarányának legalább 32 százalékra történő növelése.

- Az energiahatékonyság legalább 32,5 százalékos javítása.

A Bizottság becslései alapján a célok eléréséhez évi 260 milliárd euró összeg szükséges [COM (2019) 285 final]. A beruházásokhoz az állami és magánszektorra is szükség van, az összeg az energiaszektor, az épületek és a jármûvek beruházási igényét foglalja magába.

Az Európai Bizottság 2020. január 14-én méltányos átállási mechanizmus létrehozására tett javaslatot [COM (2020) 22 final]. A mechanizmus a fosszilis tüzelőanyagoktól való függőség vagy a kibocsátás-intenzív ipari tevékenységek révén leginkább érintett régiókra összpontosít.

Az EU klímasemlegességének megvalósítását tartalmazó javaslatot az Európai Bizottság 2020. március 4-én nyújtotta be [COM (2020) 80 final]. A bizottság a biodiverzitás helyreállítását célzó stratégiát is kialakított, melyben további védett területek kialakítását tervezi (Elekházy, 2020). 


\section{Légszennyezés terén használt indikátorok vizsgálata}

Az Európai Unió dokumentumait tekintve elkötelezett a fenntartható fejlődés megvalósítására. A fenntarthatóság irányába tett elmozdulás mérhető, ehhez indikátorokat kell használni, melyeket az Eurostat folyamatosan fejleszt.

A változások (népességnövekedés, energiafelhasználás, környezetszennyezés) a legsúlyosabb gondokat a légszennyezés terén okozzák, ami a környezetre veszélyes tevékenységek visszaszorítását igényli. Az indikátorok értékeinek változása alapján lehet cselekedni. A kulcskérdés az energiafelhasználás hatékonyságának javitása és a kevésbé szennyező energiaforrások és technológiák használata Marselek et al. (2005).

A légszennyezés terén a következő főbb indikátorok kerülnek bemutatásra:

- Nemzetgazdasági ágak üvegházhatású gáz kibocsátása;

- Nemzetgazdasági ágak széndioxid (CO2) kibocsátása;

- Nemzetgazdasági ágak ózon prekurzor kibocsátása;

- Nemzetgazdasági ágak nem metán illékony szerves vegyületek (NMVOC) kibocsátása;

- Nemzetgazdasági ágak 10 $\mu$ m átmérő alatti szálló por (PM10) kibocsátása.

A káros anyagok összesített kibocsátása kerül bemutatásra (a háztartási kibocsátás nélkül). Általában az értékek elfogadhatók, de a szálló por (PM10) kibocsátás ma is magas.

A levegő tisztasága a földi élet minőségét alapvetően befolyásolja. A légszennyező anyagok károsítják a vegetációt és környezetünket. A levegőszennyezést konkrét gazdasági ágakhoz, ágazatokhoz kell kapcsolni, hogy más gazdasági, társadalmi és környezeti mutatókkal összehasonlítható adatokkal rendelkezzünk.

A klímaváltozás szempontjából az üvegházhatású gázok a legkárosabbak. Ezen gázok kibocsátásának csökkentése nemzetközi összefogást igényel.

2050-re az EU klíma semlegessé kíván válni, ami azt jelenti, hogy csak annyi üvegházhatású gázt bocsát ki, amennyit meg tud kötni vagy ellensúlyozni képes (pl. erdőtelepítéssel).

\section{A nemzetgazdasági ágak üvegházhatású gázkibocsátása Magyarországon}

Az indikátorok a hét üvegházhatású gáz (CO2 - széndioxid, $\mathrm{CH} 4$ - metán, NO2 - di nitrogénoxid, HFC - fluorozott szénhidrogén, PFC perfluor-carbon, SF6 - kén hexafluorid, NF3 nitrogén trifluorid) kibocsátását mutatják CO2 egyenértékre átszámolva (5. ábra.) 


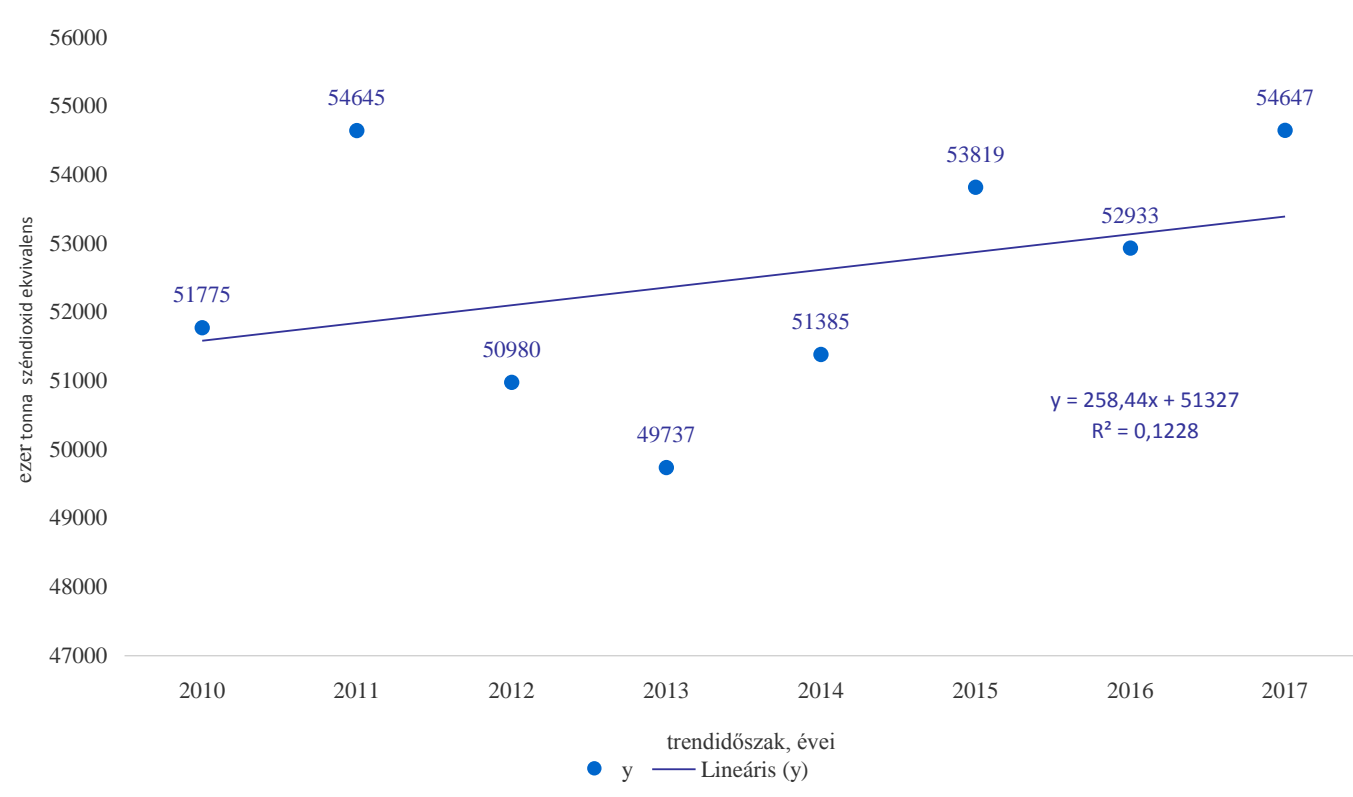

5. ábra: Nemzetgazdasági ágak üvegházhatású gázkibocsátásnak lineáris trendje Magyarországon (háztartások nélkül)

Forrás: KSH, 2019 alapján, saját számitás

Az üvegházhatású gázkibocsátáson belül egyre növekvő hányadot tesz ki a közlekedés. Ennek a szektornak a kibocsátása szignifikánsan növekvő, ez okozza a kismérvű növekedést.

A CO2 kibocsátás is folyamatos kismérvű növekedést mutat. A villamos energia, gáz, gőzellátás, légkondicionálás majdnem egyharmadát adja a kibocsátásnak, de itt lassú csökkenés regisztrálható. A változás trendjét a 6 . ábra szemlélteti.

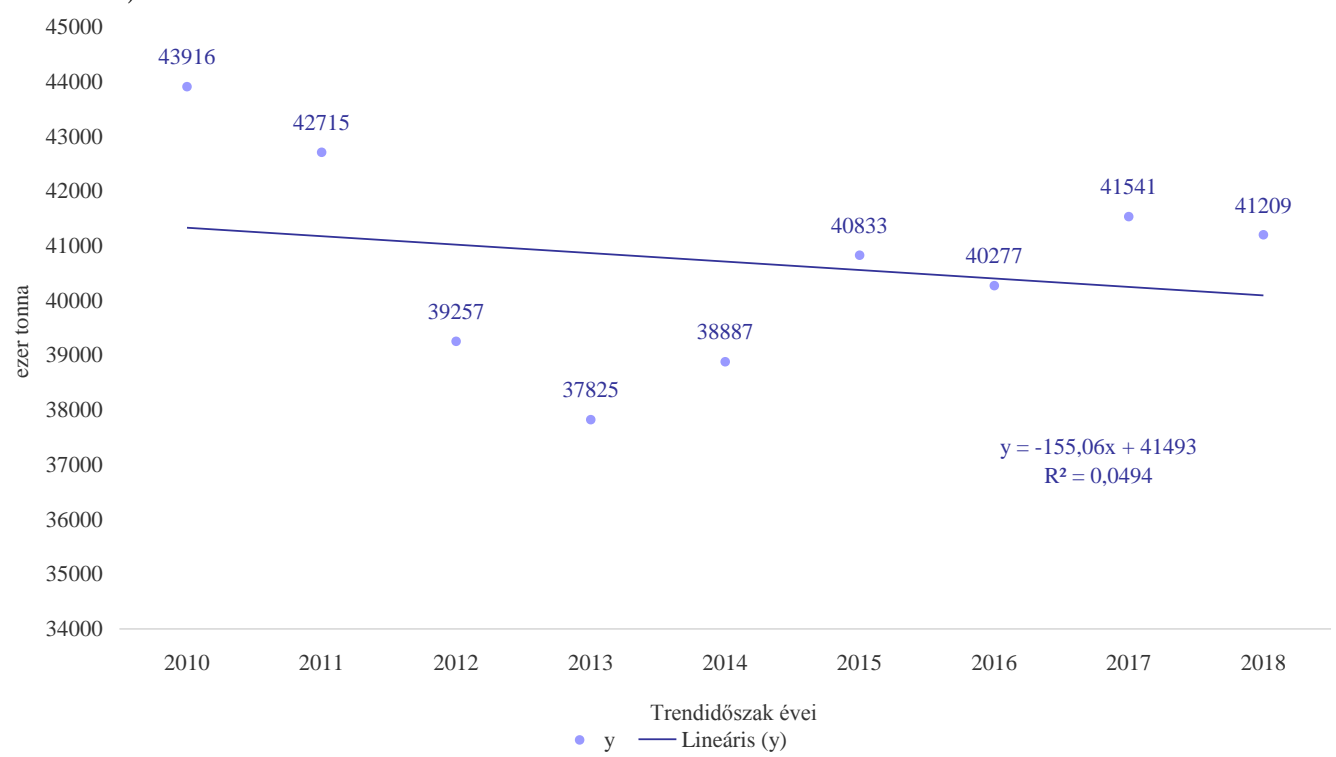

6. ábra: Nemzetgazdasági ágak széndioxid kibocsátásának lineáris trendje

Magyarországon

(háztartások nélkül)

Forrás: KSH, 2019 alapján, saját számitás 
A savasodást okozó vegyületek elsősorban az erdőket, a vízkészleteket és a talajt károsítják. A hosszabb időtávú - 1990-hez viszonyított - elemzés alapján megállapítható, hogy Magyarországon 2016-ra a kéndioxidnál 97, a nitrogén-oxidoknál 50, az ammónia esetében 42 százalékkal visszaesett a kibocsátás. A savasodást okozó gázok együttes SO2 egyenértéke az 1990 évi 1 millió 270 ezer tonnáról, 2014-re 270 ezer tonnára csökkent. Ezt a változást nagyrészt az energiaipari technológiai változások (kéntelenítő berendezések, széntüzelés visszaszorulása) okozták. A fő probléma az ammónia-kibocsátás, ami a trágyakezeléshez és a műtrágyázáshoz köthető. Az ammónia-kibocsátás 2016-ban 165 ezer tonna SO2 egyenérték volt, a savasodást okozó légszennyezô anyagok teljes kibocsátásának 61 százaléka. A savasodást okozó gázok kibocsátásának trendjét a 7. ábra mutatja be.

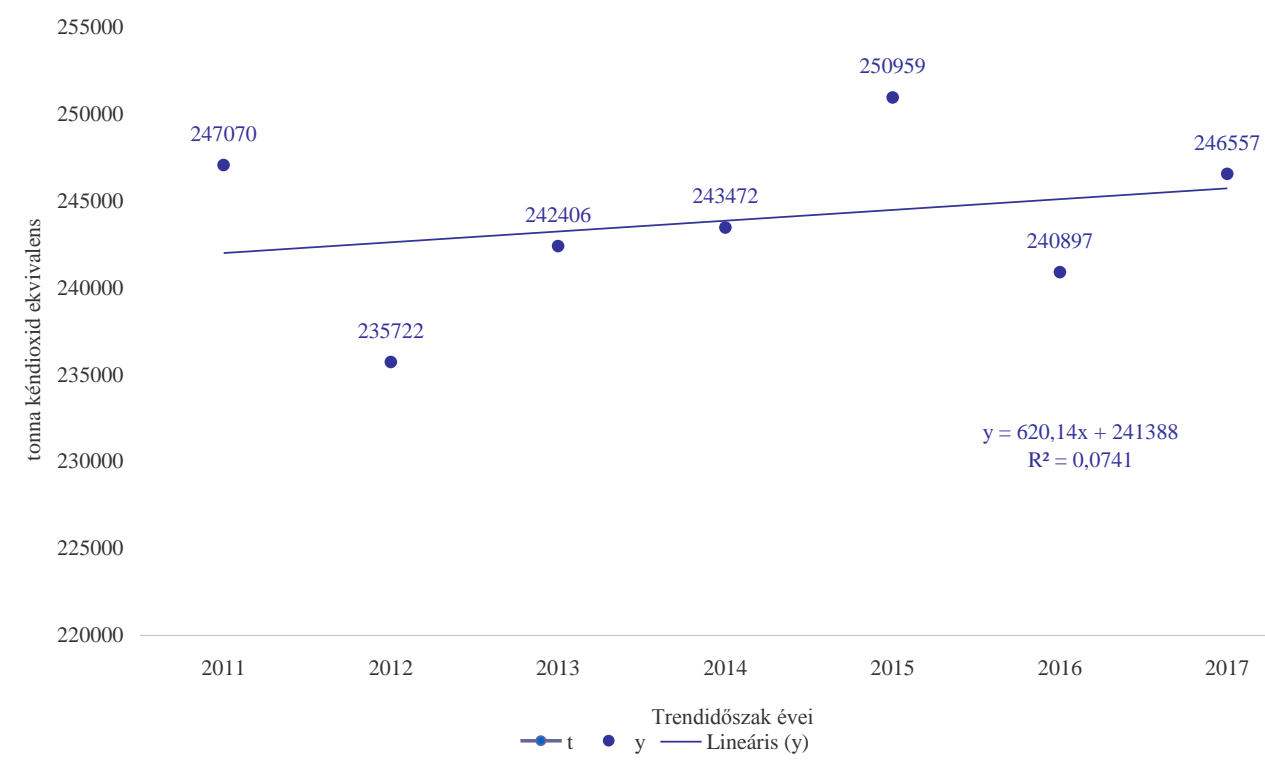

\section{7. ábra: Nemzetgazdasági ágak savasodást okozó gázok kibocsátásának lineáris trendje Magyarországon (háztartások nélkül) \\ Forrás: KSH, 2019 alapján, saját számitás}

Az ózon előanyagok (prekurzorok) hozzájárulnak a talaj közeli ózon kialakulásához. A troposzférikus ózon a szmog egyik összetevője, főleg a nagy forgalmú városokat sújtja. A gáz károsítja az ökoszisztémát, a megemelkedett ózonkoncentráció légzési problémákat okoz. A troposzférikus ózon a közlekedés, az ipar és a háztartások energiafelhasználása során keletkezik. A NMVOC esetében a háztartások, a mezőgazdaság és a feldolgozóipar emissziója számottevő.

A modern technológiák révén a terhelés csökkenthetô, így az ózon prekurzor kibocsátás csökkenő trendet mutat (8. ábra). 


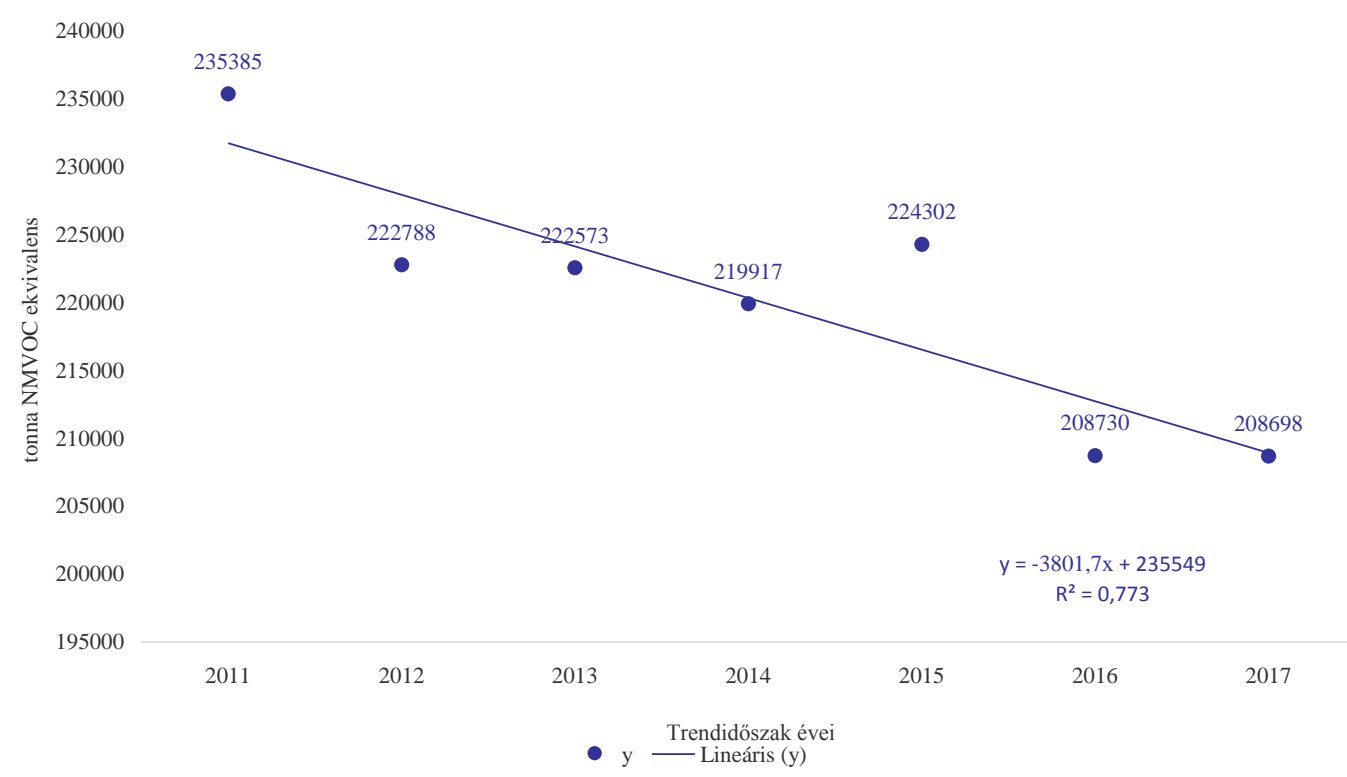

8. ábra: Nemzetgazdasági ágak ózon prekurzor kibocsátásának lineáris trendje Magyarországon (háztartások nélkül)

Forrás: KSH, 2019 alapján, saját számitás

Az ózon prekurzor emisszió az 1990-re kimutatott 766 ezer tonna NMVOC egyenértékről 2016ra 337 ezer tonnára csökkent. A fó ózon prekurzorok 2016-ban a nitrogénoxidok voltak (42\%), a nem metán illékony szerves vegyületek 42 , a szénmonoxid 15, a metán 1,3\%-kal részesedett az ózonképző vegyületek kibocsátásából.

Az NMVOC kibocsátást a 9. ábra szemlélteti.

71000

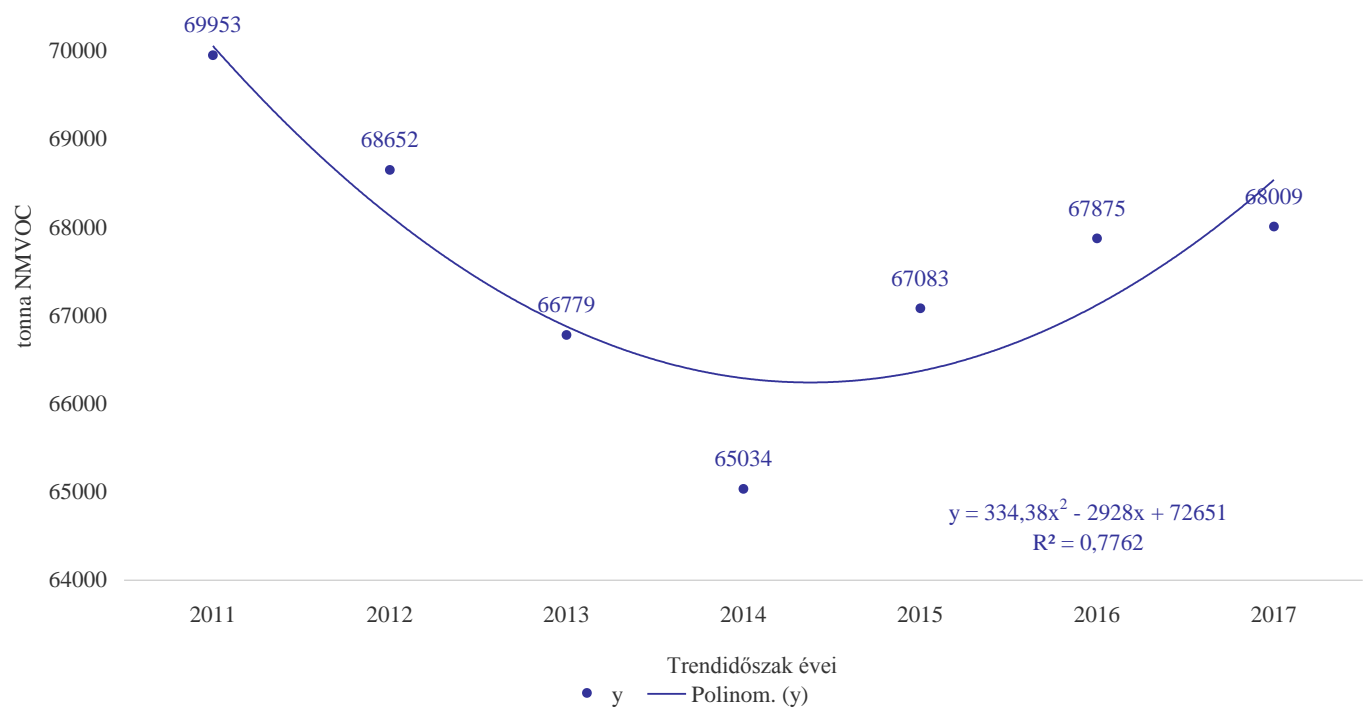

9. ábra: Nemzetgazdasági ágak nem metán illékony szerves vegyületének (NMVOC) kibocsátásának parabolikus trendje (háztartások nélkül)

Forrás: KSH, 2019 alapján, saját számítás

Csökkenés után kismérvű növekedést tapasztalhatunk. Az NMVOC kibocsátás zöme a mezőgazdasághoz kapcsolódik. 
Az uniós elvárásoknak megfelelően a szálló por 2 fajtáját különböztetjük meg a 10 mikron és az, az alatti átmérōjü részecskéket (PM10), valamint a 2,5 mikron és az, az alatti átmérőjū részecskéket (PM2,5). Az utóbbi, kisebb részecskék könnyebben eljutnak a tüdő hörgőibe, ezért magas egészségügyi kockázatot jelentenek.

2000 és 2016 között a PM10 nemzetgazdasági kibocsátása 42 ezerről 25 ezer tonnára, ezen belül a PM2,5 emissziója 16 ezerrôl 7 ezer tonnára csökkent. A szálló por kibocsátás a mezőgazdaságból a szállítás, raktározásból az ipari, a háztartási és egyéb tüzelésből ered (KSH, 2018).

\section{Következtetések és javaslatok}

Hazánk a jövőt illetően stratégiai kihívások előtt áll. Szükséges lenne megvalósítani:

- az erőforrások takarékos használatát,

- a fokozott felkészülést a klímaváltozásra,

- a környezetszennyezés jelentős visszafogását,

- új innovatív technológiák bevezetését,

- elmozdulást a Zöld Gazdaság felé.

A KSH adatsorai általában javuló szennyezési adatokat mutatnak, de nem lehetünk elégedettek. Az Európai Zöld Megállapodás ambiciózus terv, de át kell gondolni, hogy a megvalósítás során senki ne járjon rosszul. Arra kell törekedni, hogy a 2oC hőmérsékletemelkedés ne valósuljon meg, mert ez a változás ismeretlen és kiszámíthatatlan veszélyeket jelent.

A fenntarthatósági indikátorok változásait folyamatosan elemezni kell, negatív változások esetén szükséges a beavatkozás.

\section{Hivatkozott források}

[1.] A Fenntartható Európa beruházási terv (2020): [COM (2020) 21 final]

[2.] Az Európai Zöld Megállapodás [COM (2019) 640 F/1], 1-4. pp.

[3.] Csete L. - Láng I. (2005): A fenntartható agrárgazdaság és vidékefejlesztés. MTA Társadalomkutató Központ Budapest, 1-313. p.

[4.] Elekházy N. (2020): Az Európai Zöld Megállapodás. Országgyülés Hivatala, 52. sz. 1-4. pp.

[5.] European Commission (2010): Europe 2020: a strategy for smart, sustainable and inclusive growth. Brussels 3.3. 2010. [COM (2010) 2020 final]

[6.] Javaslat az Európai Parlament és a Tanács rendelete a klímasemlegesség elérését célzó keret létrehozásáról és az EU 2018/1999 rendelet (az európai klímarendelet módosításáról [COM (2020) 80 final]

[7.] Javaslat az Európai Parlament és a Tanács rendelete a Méltányos Átállást Támogató Alap létrehozásáról [COM (2020) 22 final]

[8.] Központi Statisztikai Hivatal (2018): Környezeti helyzetkép. Budapest, 1-110. p.

[9.] Központi Statisztikai Hivatal (2019): A fenntartható fejlődés indikátorai Magyarországon 2018. Budapest, 1-241. p.

[10.] Láng I. - Csete L. - Jolánkai M. (2007): A globális klímaváltozás - bazai hatások és válaszok. Szaktudás Kiadó Ház Rt. Budapest,

[11.] Láng I. (2003): A fenntartható fejlódés Johannesburg után. Agroinform Kiadóház Budapest, 1-147. p. 
[12.] Lorenz K. (1973): Die acht Todsünden der zivilisierten Menschbeit R. Piper Sz Co. Verlag, München 1-102.p.

[13.] Magda R. (2010): Földhasználat és fenntarthatóság. Gazdálkodás, 64(2), 160-168

[14.] Marselek S. - Abayné Hamar E. - Wölcz A. (2005): A fenntartható fejlódés lehetöségei, feladatai, eszközrendszere és javasolható indikátorai. Környezetvédelem, regionális versenyképesség, fenntartható fejlődés. Tudományos Konferencia Pécs, 7-15. pp.

[15.] Marselek S. (2005): Az észak-magyarországi régió fenntartható fejlódésének lehetöségei. „Agrárgazdaság, Vidékfejlesztés, Agrárinformatika” Nemzetközi Konferencia Debrecen, 1-6. p. (CD lemezen)

[16.] Marselek S. (2006): Környezeti állapot, mezőgazdaság, fenntartható fejlődés. Gaz̧dálkodás, 50 (15), 17-27

[17.] Összefogás az energiaunió és az éghajlat-politika terén - A tiszta energiára való átállás feltételeinek megteremtése [COM (2019) 285 final]

[18.] VAHAVA (Változás - Hatás - Válaszadás) projekt: A globális klímaváltozás hazai hatásai és az arra adandó válaszok. Magyar Tudományos Akadémia, 2003-2006.

\section{Szerző}

Szűcs Csaba

ORCID: 0000-0003-3099-3050

$\mathrm{PhD}$

Egyetemi docens

Magyar Agrár- és Élettudományi Egyetem Károly Róbert Campus Gyöngyös

szucs.csaba@uni-mate.hu 